\title{
The Responsibility of Member States of International Organizations
}

\section{Concluding Observations}

\author{
Cedric Ryngaert \\ Professor of Public International Law, Utrecht University \\ C.M.J.Ryngaert@uu.nl
}

\section{Introduction}

The ten contributions to this special forum have each brought to the fore various aspects of the responsibility of member States in connection with the acts of international organizations. This concluding contribution aims to bring together the different arguments.

The contribution starts by pointing out, in Section 1, that the separate legal personality of the international organization and its member States, and the autonomy enjoyed by the international organization vis-à-vis its member States, does not mean that member States participating in institutional settings entirely disappear behind the international organization, including for responsibility purposes. Within these settings, member States retain some autonomous, discretionary powers which form the basis for their responsibility in connection with international organization action. The linchpin for a finding of member State responsibility is the issue of attributing conduct or responsibility to the member State rather than (only) to the international organization. Specific principles of attribution have been suggested by the International Law Commission ('ILC') in the Articles on the Responsibility of International Organizations for Internationally Wrongful Acts ('ARIO'). As argued in Section 3, in many scenarios of joint or parallel international organization-member State action within institutional settings, conduct or responsibility can, on the basis of the familiar principles of attribution, in fact, be imputed to both the international organization and its member State(s). This dual attribution could result in the international organization and the member

* The research which resulted in this publication has been funded by the European Research Council under the Starting Grant Scheme (Proposal 336230 - UnIJURIS) and the Dutch Organization for Scientific Research under the VIDI Scheme (No 016.135.322). 
State(s) sharing responsibility. It is cautioned, however, that international organizations and member States should not too readily share responsibility, particularly not when one of the actors is not 'blameworthy' as that term should properly be understood.

Throughout the contributions to this special forum, it has become apparent that the principles governing the responsibility of member States are primarily doctrinal constructs which have not yet garnered a strong foothold in legal practice. Nevertheless, as pointed out in Section 4, the responsibility of member States has been invoked in a number of dispute-settlement fora, including before domestic courts. However, there remain major practical and doctrinal obstacles to the successful invocation of the responsibility of member States. Such obstacles could be overcome, but it is crucial that member States are ultimately not held responsible by virtue of their mere membership of an international organization. Where remedies against international organizations are lacking, the solution is not to allow claims to be vicariously directed against the member States but rather to strengthen remedies against the international organizations themselves. Even then, however, the mechanism of member State responsibility may prompt member States to make an additional effort to improve the quality of remedies at the level of the international organization. As creators of international organizations, it may be argued that member States have a duty to ensure that international organizations comply with basic rule of law prescriptions and establish adequate procedures that protect the rights of third parties.

\section{2 \\ The Autonomy of the International Organization vis-à-vis Its Member States}

International institutional lawyers are wont to emphasize the autonomy of international organizations, and that their legal personality should be separate from their member States'. International organizations have become powerful actors which have their own agency and cannot be reduced to fronts for their founding fathers, the member States.

As d'Aspremont points out, it can be argued that the ARIO, while aiming to restrain international organization power through responsibility (accountability) rules, have further cemented the power of international organizations, even more than the conferral of international legal personality on international organizations has done. ${ }^{1}$ The ARIO make it clear indeed that

1 It could thus be submitted that in the history of international institutional law, the ARIO may have had more empowering effect than the Reparation for Injuries case (Reparation for Injuries Suffered in the Service of the United Nations, 11 April 1949, International Court of 
international organizations have the capacity to aid, coerce, or direct other actors - States in particular - to commit international wrongfully acts, ${ }^{2}$ which implies that their power may exceed that of States.

Such scenarios of abuse of power are not common, however. In the ordinary course of events, international organizations exercise their powers with a view to discharging the functions legally assigned to them in their constitutional documents: they are not normally inclined to engage in wrongful conduct. For the effective exercise of these powers, it is crucial that international organizations need not be concerned by the risk of micro-management of member States. A legally-anchored autonomy for the international organization may go a long way to prevent intervention by their creators. Rules of international responsibility are important tools in this respect. Where such rules too easily allow for a member State's responsibility to be engaged for, or in connection with the acts of an international organization (in particular through overbroad rules of attribution), it is to be expected that member States will intervene in the international organization's affairs so as to prevent wrongful acts from being committed. Such an outcome would effectively scutthe the international organization's autonomy, drastically reduce its effectivité, and eventually possibly reduce global welfare, which is normally boosted by international cooperation. This explains why Blokker has warned of the danger of doctrines of member State responsibility, citing, among other risks, the risk that, with respect to international military operations, member States will upset institutional command structures, and, even worse, that they may refrain from contributing troops for fear of being held responsible if operations go wrong.

From this perspective, member States should certainly not be held responsible by virtue of their membership alone. ${ }^{3}$ Such a rule would unfairly allocate responsibility to actors who were not in a position to prevent wrongful conduct and would have dire effects for the functioning of international organizations. It remains, however, that, in spite of the separate international legal personality and the autonomy of international organizations, member States do not entirely disappear behind the international

Justice, Advisory Opinion, [1949] ICJ Reports p. 174), which for the first time recognized the separate international legal personality of international organizations.

2 International Law Commission, Articles on the Responsibility of International Organizations (2011), UN Doc. A/RES/66/10o and the accompanying Commentaries ('ARIO and Commentaries'), Arts. 14-17.

3 Resolution II, (1995) 66(1) Annuaire de l'Institut de Droit International p. 445; ARIO and Commentaries, supra note 2, commentary to Article 62. 
organization's institutional veil (to use the elegant phrasing of Catherine Brölmann). The organization retains a measure of transparency, meaning that the member States remain discernible, with important consequences for responsibility. Within international institutional settings, or in connection with international institutional action, member States continue to pursue autonomous policies. This goes to show, as Wessel and Dekker have pointed out in their contribution, that member States can take on different qualities and functions in relation to the work of international organizations and, in spite of the autonomy of the international organization, do not disappear. Ana Sofia Barros, for her part, emphasizes that member States' transfer of competences to international organizations is a continuous one, with member States in fact taking part in the exercise of international organization power or at least having a duty to manage the exercise of authority by international organizations. Some of the qualities and functions of member States in relation to international organizations have particular relevance for responsibility purposes.

First, member States may, often via their voting power, push or obstruct particular projects within international organization organs that are composed of member State representatives, such as the UN Security Council or the Board of Executive Directors of international financial institutions. It would be quite a stretch to attribute such voting behaviour to the international organization: the better view is that it is the member State's own conduct. ${ }^{4}$ Ana Sofia Barros thus highlights that autonomous conduct of member States in connection with international organization decision-making could engage their international (State) responsibility and that due diligence obligations, such as those drawn from international human rights law, are incumbent on them when acting within international organizations. Along similar lines, the ICJ, in the Interim Accord Case (2011), held Greece, as a member State of NATO, responsible for objecting and acting to prevent the former Yugoslav Republic of Macedonia ('FYROM') from receiving an invitation to proceed to NATO membership, ${ }^{5}$ in violation of an Interim Accord (1995), whereby Greece had agreed "not to object to the application by or the membership of [FYRом] in international, multilateral and regional organizations and institutions of

4 Ana Sofia Barros and Cedric Ryngaert 'The Position of Member States in (Autonomous) Institutional Decision-Making: Implications for the Establishment of Responsibility' (2014) 11(1) International Organizations Law Review pp. 53-82.

5 Application of the Interim Accord of 13 September 1995 (FYRM v. Greece), 5 December 2011, International Court of Justice, [2011] ICJ Reports p. 644, at p. 66o, para. 42. 
which [Greece] is a member". 6 According to the International Court of Justice ('ICJ'), the question before it was "not whether the decision taken by NATO ... with respect to the Applicant's candidacy was due exclusively, principally, or marginally to [Greece's] objection", but whether Greece "by its own conduct, did not comply with the obligation not to object contained in Article 11, paragraph 1, of the Interim Accord".

Secondly, autonomous member State action could be found in an operational context, where the member State places its organs at the disposal of the international organization for the conduct of operations mandated and commanded by an international organization. Insofar as the member State continues to exercise effective control over these organs, will wrongful conduct carried out by these organs be attributed to the member State and engage the member State's responsibility in accordance with the law of state responsibility. ${ }^{8}$ Notably in multinational military operations under the auspices of the UN or a regional organization, this principle has major traction, as discussed by Tom Dannenbaum. Relatedly, a measure of autonomous member State action may take place where member States implement decisions of international organizations, who may have been allocated competences but no implementation or enforcement powers of their own. The role of member States as law-implementers begs the question as to whether their responsibility is, or should be, engaged when international law violations take place when implementing international organization obligations.

Thirdly, member States may use their influence to cause international organizations to perform particular conduct, namely where they aid or assist the international organization, direct or control it, coerce it, or take advantage of its competences. Such conduct, if an internationally wrongful act, may engage the responsibility of both the international organization and the intervening member State: while the conduct may be attributed to the international organization, the responsibility may also be attributed to the member State. Part $\mathrm{v}$ of the ARIO gives an overview of the relevant principles. It also adds that member States could incur subsidiary responsibility where they have accepted responsibility for a wrongful act towards the injured party or have led the

6 Interim Accord between the Hellenic Republic and the FYROM, 13 September 1995, extracted in Application of the Interim Accord, supra note 5.

7 Application of the Interim Accord, supra note 5, para. 70.

8 Art. 7 of the ARIO a contrario ("The conduct of an organ of a State or an organ or agent of an international organization that is placed at the disposal of another international organization shall be considered under international law an act of the latter organization if the organization exercises effective control over that conduct"). 
injured party to rely on their responsibility, ${ }^{9}$ a scenario that may occur where, in the constitutional document of the international organization, member States lay down such subsidiary responsibility, such as for debts or other liabilities of the organization.

One of the key issues determining the allocation of responsibility between international organizations and their member States pertains to who, within a complex, multi-layered normative and operational institutional setting, precisely controlled, decisively influenced, or accepted a fateful decision leading to a violation of international law. In deceptively simple terms, this is the issue of where the international organization begins and the member States end, or vice versa, which was unpacked by Ramses Wessel and Ige Dekker in their opening contribution. For it is a cornerstone of the law of responsibility that an actor can only be held responsible where the impugned acts could be attributed to it, or where it is somehow connected to these acts. Specific rules of attribution of conduct and responsibility between international organizations and their member States feature in the ARIO (some of them borrowed from the ARS), such as control, direction, coercion, acceptance, and circumvention. All of them base attribution, and ultimately responsibility if an actual violation of international law is found, on the proximity of an actor to a particular conduct (attribution of conduct), or the proximity of an actor to another actor to whom the wrongful conduct has been attributed (attribution of responsibility).

On the basis of the rules of attribution, it is by no means excluded that conduct or responsibility is simultaneously attributed to the international organization and its member State(s): for example, where both exercise effective control over wrongful conduct, or where one directs the other to commit an internationally wrongful act. The responsibility of international organizations and their member States can then be considered as shared. Shared responsibility via dual attribution need not be exceptional. In cooperative undertakings between international organizations and member States it may possibly be the rule rather than the exception. Three scenarios spring to mind:

9 Art. 62 of the ARIO. Note that some of the principles discussed in Part V of the ARIO, notably Arts. 58, 59 and 6o, may not only apply to member States, but to any States, even when they are not members of the relevant international organization. See ARIO and Commentaries, supra note 2, commentary (4) to the chapeau of Part V of the ARIO. 
(1) the conduct of UN peace operations; (2) the imposition of UN sanctions; and (3) mixed agreements to which both the EU and its member States are parties.

First, UN peace operations may be structurally predisposed towards shared responsibility, as member States place troop contingents at the disposal of an international organization, and a complex command structure is typically set up, involving a UN and a national force commander, who in turn may be influenced by un headquarters or national capitals as the case may be. Where these troops commit or fail to prevent violations, both the UN and the member State may exercise a measure of effective control over the relevant conduct, which on that basis may be attributed to both. As Tom Dannenbaum notes in his contribution, such dual attribution was in fact implied by Dutch courts in the Srebrenica litigation and by the European Court of Human Rights ('ECtHR') in the AlJedda case.

Dual attribution may also be found in another, not uncommon, scenario of international organization-member State cooperation, namely the imposition of UN sanctions against suspected terrorists or terrorist supporters. Such sanctions are decided at the level of the UN, transformed into statutory law by regional organizations (such as the $\mathrm{EU}$ ) and/or member States, and applied against individuals or entities by member States. Where such sanctions are not in compliance with international human rights law, both the UN and the member States implementing them may share international responsibility, as Antonios Tzanakopoulos has observed. The sanctions physically applied against a particular person are obviously attributable to the State as the implementing actor; but, assuming that the state is legally bound to apply sanctions ordered by the UN Security Council (pursuant to Article 25 of the UN Charter) and is not just exercising its discretion, the UN, as the controlling or deciding organization, may also have the relevant conduct, or at least responsibility for that conduct, attributed to it.

Thirdly, dual attribution, and the ensuing shared responsibility of the international organization and its member State, as Esa Paasivirta has highlighted, may be the default position with respect to mixed international agreements with third parties to which both the EU and its member States are parties. Third parties should not be adversely affected by an internal division of competences between international organizations and their member States and should thus be allowed to invoke the responsibility of both for the violation of the agreement. Thus, the Draft EU-Singapore Free Trade Agreement provides that the EU and its member States shall not assert "the inadmissibility of a claim, or otherwise assert that a claim or award is unfounded or invalid, on the ground that the proper respondent should be or should have been the Union 
rather than the member State or vice versa". ${ }^{10}$ If the EU and the member States would like to avoid a finding of joint responsibility, they could always communicate to third parties the exact division of competences between them in respect of the implementation of the agreement so that these parties could take an informed decision as to whose responsibility to invoke for a violation. Insofar as this division of competences is not updated, of course, as Brölmann observed, such division cannot be opposed to third parties, with the attendant consequences for responsibility. To a certain extent, joint EU-member State responsibility as the default responsibility regime ${ }^{11}$ is also how the corespondent mechanism under the EU-ECHR Draft Accession Agreement ${ }^{12}$ will operate. Pursuant to this mechanism, where an individual directs an application regarding a violation of the European Convention on Human Rights against one or more member States of the European Union, the EU may in some circumstances become a co-respondent to the proceedings in respect of an alleged violation notified by the Court; if subsequently a violation is established, the Agreement provides that the respondent and the co-respondent shall be jointly responsible for that violation. ${ }^{13}$

In scenarios of joint international organization-member State action, dual attribution or shared responsibility should not be found too readily, however, as it may well be that one of the actors involved has no individual agency or power to prevent the wrongful conduct. Thus, Dannenbaum criticises the Hague District Court judgment's implication in the Mothers of Srebrenica litigation (2014) that the relevant conduct - the expulsion of Bosnian civilians from a mini safe area where they had sought refuge - might also be attributable to the United Nations, and not just to the Netherlands as the troop-contributing state, on the ground that in the particular case, the UN, unlike the Netherlands, did not hold 'key levers of obedience-generating control'. Somewhat similarly, one may wonder whether a member State faithfully implementing a sanctions resolution of the UN Security Council binding on it is anyhow blameworthy. Conscious of the need to offer accountability to victims of sanctions, courts have made ingenious attempts to hold member States (or the EU) responsible.

$10 \quad$ Art. 9.15(4) of the draft EU-Singapore Free Trade Agreement.

11 Note that Brölmann, in her contribution to this special forum, takes issue with the characterization of such joint responsibility as the default responsibility regime. Instead, she argues, descriptively, that ad hoc arrangements on responsibility are normally made.

Council of Europe, Fifth negotiation meeting between the $C D D H$ ad hoc negotiation group and the European Commission on the Accession of the $E U$ to the European Convention on Human Rights, Council of Europe Document 47+1(2013)oo8rev2, Strasbourg, 10 June 2013. Ibid., Article 3(7). 
In the Kadi case, the Court of Justice of the EU famously turned a blind eye to the international normative source of the anti-terrorist sanctions imposed by the UN and held the EU liable for violations of EU fundamental rights protections. ${ }^{14}$ In the Nada case, the ECtH R held Switzerland responsible for violations of the European Convention on Human Rights, on the ground that it exercised its discretion when implementing UN sanctions, even when Switzerland did little more than implement resolutions that were legally binding on it. ${ }^{15}$ Such decisions may seem to unfairly target member States (or the EU), but as Tzanakopoulos has pointed out, they not only implement the responsibility of the member State but also that of the UN, as they serve as a mechanism of pressure for the UN to change its ways, lest its decisions remain unimplemented. More generally, when EU member States do no more than implement binding $\mathrm{EU}$ decisions and in fact just act as agents of the $\mathrm{EU}$ (which indeed relies on its member States as EU law-enforcement agencies), it would be somewhat incongruous to hold a member State responsible alongside the EU. As Paasivirta suggests in this respect, responsibility may have to be based on competence; thus, where a member State exercises the EU's competences, the responsibility may have to lie with the EU. The International Tribunal for the Law of the Sea has held as much in its advisory opinion in Case No. 21, holding that

where an international organization, in the exercise of its exclusive competence in fisheries matters, concludes a fisheries access agreement with [a member State of the Sub-Regional Fisheries Commission, a West African international organization] only the international organization may be held liable for any breach of its obligations arising from the fisheries access agreement, and not its member States ${ }^{16}$

even if the pertinent fishing vessel flies the flag of a member State. Obviously, that a regional economic integration organization such as the $\mathrm{E} U$ has exclusive competences over a number of subject-matters may be well-known to third parties so that they are put on notice that responsibility claims should be

14 Yassin Abdullah Kadiand Al Barakaat International Foundation v. Council and Commission, 3 September 2008, European Court of Justice, Joined cases C-402/05 P and C-415/05, [2008] ECR I-6351.

15 Nada v. Switzerland, 12 December 2012, European Court of Human Rights, App. No. 10593/08.

16 Request for an Advisory Opinion Submitted by the Sub-Regional Fisheries Commission, 2 April 2015, International Tribunal for the Law of the Sea, Advisory Opinion, Case No. 21, available at: <www.itlos.org/en/cases/list-of-cases/case-no-21/>, paras. 172 and 174. 
directed to the international organization rather than the member State. However, even in case of shared or parallel competences, the third party may want to inquire what competences belong to the international organization and the member State. As a result, a finding of joint international organization-member State responsibility in case of international law violations is not a natural occurrence.

\section{4}

\section{Invocation of Responsibility}

As is also the case in general international law, the allocation of responsibility between member States and international organizations is primarily determined by the member States and international organizations themselves, as dispute-settlement mechanisms with jurisdiction over international responsibility questions are largely absent. Over the years, States and international organizations have paid little attention to the intricacies of member State responsibility, however. Even in the consultation round organised by the ILC in the context of its work on the ARIO, input from States and international organizations on the issue was rather scarce. As a result, the principles of member State responsibility are largely a doctrinal creation flowing from the application per analogiam of categories found in the earlier ILC ASR, or simply from common sense. In the commentaries to the relevant ARIO principles, at any rate, little state and institutional practice can be discerned. How such practice develops after the adoption of the ARIO, is likely to be strongly influenced by the choices made by the drafters of the ARIO.

Mechanisms that can settle disputes over the allocation of responsibility between member States and international organizations are not entirely absent, however. While international courts do not normally have jurisdiction over international organizations, they do have jurisdiction over States. Similarly, while the immunity of international organizations will normally bar domestic courts' exercise of jurisdiction over international organizations, these courts have jurisdiction over States, at least their own State. The responsibility of member States could thus well be litigated in court. Case-law from the ECtHR, the ICJ, and some domestic courts demonstrates the potential of such litigation. The EctHr has addressed member State responsibility head-on in the context of attributing conduct to states contributing troops to multinational operations under UN auspices (Behrami and Al Jedda), ${ }^{17}$ as well as in a

17 Joined cases Behrami and Behrami v. France, 2 May 2007, European Court of Human Rights, App. No. 71412/01 and Saramati v. France, Germany And Norway, 2 May 2007, 
string of cases concerning the responsibility of member States for EU conduct (starting with Bosphorus). ${ }^{18}$ The ICJ has obliquely touched upon the issue in a number of cases (Phosphates, Application Interim Agreement). ${ }^{19}$ The most pertinent case brought before the ICJ, concerning the responsibility of NATO member States for the NATO bombing of Serbia in 1999, was aborted for jurisdictional reasons at an early stage of the proceedings. ${ }^{20}$

Domestic courts, for their part, have hardly addressed member State responsibility, with the notable exception of Dutch courts. In a number of high-profile cases with respect to the 1995 massacre in Srebrenica (Bosnia-Herzegovina) filed by victims' relatives against the State of the Netherlands - which had contributed troops to the UN operation in Bosnia - Dutch courts held the state responsible for delivering Bosnian men into the hands of Bosnian Serb militia, in the knowledge that in all likelihood they would be killed. ${ }^{21}$ The courts' decisions are well-reasoned and make abundant reference to international law, in particular to Article 7 of the ARIO, which enshrines the effective control standard as a standard to allocate responsibility in international military operations. Having been translated immediately into English, they have garnered the attention of international legal scholarship ${ }^{22}$ and may well have impact in other jurisdictions confronted with questions of allocation of

European Court of Human Rights, App. No. 78166/o1; Jedda v. United Kingdom, 7 July 2011, European Court of Human Rights, App. No. 27021/o8, 30 в нRс 637.

18 Bosphorus Hava Yollari Turizm Ve Ticaret Anonim Şirketi v. Ireland, 30 June 2005, European Court of Human Rights, App. No. 45036/98, (2006) 42 European Human Rights Reports p. 1.

19 Certain Phosphate Lands in Nauru (Nauru v. Australia), 26 June 1992, International Court of Justice, Preliminary Objections, [1992] ICJ Reports p. 240. Application of the Interim Accord, supra note 5 .

20 Legality of the Use of Force (Federal Republic of Yugoslavia v. France), 15 December 2004, International Court of Justice, Preliminary Objections, [2004] ICJ Reports p. 575.

21 Nuhanović v. Netherlands, 5 July 2011, Gerechtshof 's-Gravenhage, Appellate Judgment, LJN: BR 5388; Mustafic v. Netherlands, 5 July 2011, Gerechtshof's-Gravenhage, Appellate Judgment, LJN: BR5386; Mothers of Srebrenica v. Netherlands, 17 July 2014, Rechtbank 's-Gravenhage, LJN: 8748/C/og/295247.

22 E.g. Bérénice Boutin, 'Responsibility of the Netherlands for the Acts of Dutchbat in Nuhanović and Mustafić: The Continuous Quest for a Tangible Meaning for "Effective Control" in the context of Peacekeeping' (2012) 25(2) Leiden Journal of International Law pp. 521-535; Paolo Palchetti, 'Attributing the Conduct of Dutchbat in Srebrenica: The 2014 Judgment of the District Court in the Mothers of Srebrenica Case' (2015) Netherlands International Law Review pp. 279-294. 
responsibility in international military operations to which the forum state has contributed troops. As Francesco Messineo warns, however, legal and practical obstacles may stand in the way of domestic courts entertaining such cases. In other jurisdictions where cases against the State have been brought, notably the United Kingdom and Germany, courts have declared cases involving military operations abroad non-justiciable or ruled that individuals are not entitled to invoke international responsibility norms in domestic claims processes. Costs are obviously an additional complicating factor, which in the Dutch Srebrenica cases happened to be overcome because foundations supported the claimants. ${ }^{23}$ States are well-advised to remove remaining obstacles to litigation concerning the responsibility of member States in domestic courts.

Even where courts can entertain cases pertaining to member State responsibility, as Paolo Palchetti has observed, account should however also be taken of the indispensable third party doctrine, as enunciated by the ICJ in the Monetary Gold Case.$^{24}$ Pursuant to the Monetary Gold principle, a court cannot exercise its jurisdiction over a dispute when the legal interests of a third party (being a party not before the court) would form the very subject-matter of the decision. ${ }^{25}$ This principle may prove to be a serious obstacle to successful litigation against member States with respect to the allocation of responsibility in connection with international organization conduct, as a decision on the responsibility of the State may almost inevitably impact on the legal position of the international organization: holding that a member State is attributed responsibility in connection with international organization conduct may presuppose the attribution of conduct to the international organization. As Palchetti rightly observes, however, a narrow interpretation of Monetary Gold

23 Stichting Mothers of Srebrenica and Nuhanovic Foundation. The latter foundation was established in 2011, on account of one of the Srebrenica cases (Nuhanović v. State of the Netherlands, supra note 21), by a number of leading litigators and specialists in the field of accountability and remedies for violations of international humanitarian law. According to its mission statement, the Foundation "assist[s] war victims who seek access to justice to obtain a remedy in the form of reparation, restitution or compensation", and "provide funds for investigations and legal representations in negotiations and litigation": see its webstie, available at:<www.nuhanovicfoundation.org/en/our-mission/>. The Foundation also supports litigation outside the Netherlands.

24 Monetary Gold Removed from Rome in 1943 (Italy v. France; United Kingdom and United States of America), 15 June 1954, International Court of Justice, Preliminary Question, [1954] ICJ Reports p. 19.

Ibid., p. $3^{2}$. 
in such cases is called for, as further limitations to the jurisdiction of courts over issues of member State responsibility are undesirable. Where derived member State responsibility does not require international wrongfulness on the part of the international organization - and even more, where courts do not have jurisdiction over international organizations in the first place the Monetary Gold principle may not applicable, and cases against member States can move forward, perhaps subject to a rule that affected international organizations are allowed to make observations. So far, in any event, Monetary Gold has not played a role in judicial decisions with respect to member State responsibility, although the principle was invoked by the parties in various cases. ${ }^{26}$

In an international society aspiring to be based on the rule of law, external judicial intervention to settle disputes involving the responsibility of member States in connection with international organization action is surely to be applauded. However, as in other areas of life, such intervention, while not belittling its relevance, should be a last resort. Preferably, victims of institutional action, even if involving member States, can avail themselves of remedies offered by the international organization itself. The recent surge of judicial accountability efforts targeting member States is nevertheless understandable insofar as these remedies have not been, or have not been sufficiently, forthcoming. In many cases, victims have vicariously proceeded against member States, where in fact blame should have also, or even largely, been assigned to an international organization, which was nevertheless not amenable to suit for jurisdictional reasons. Thus, victims of violations committed in international military operations have tended to file suit against troop-contributing nations rather than international organizations, ${ }^{27}$ and individuals appearing on UN

26 Banković and others v. Belgium and 16 other States, 12 December 2001, European Court of Human Rights, App. No. 52207/99, para. 32; Joined cases Behrami and Behrami v. France, 2 May 2007, European Court of Human Rights, App. No. 71412/01 and Saramati v. France, Germany And Norway, 2 May 2007, European Court of Human Rights, App. No. 78166/o1; Legality of the Use of Force, supra note 20; and Application of the Interim Accord, supra note 5 , as cited in Paolo Palchetti's contribution to this special forum.

27 In rare cases, the international organization itself has also been targeted, but international organization immunity will ordinarily be found and serve as a procedural bar to further proceedings. See the case brought in the Netherlands against the UN in respect of the Srebrenica massacre: Mothers of Srebrenica, supra note 21, (confirming the functional immunity of the UN), as upheld by the ECtHR (see Stichting Mothers of Srebrenica v. Netherlands, 11 June 2013, European Court of Human Rights, App. No. 65542/12. 
anti-terrorism sanctions lists have filed suit against implementing states and regional organizations rather than against the UN. Judgments rendered in such cases may hold member States responsible, sometimes for good reason. However, such decisions may shoot the pianist rather than the composer. As of necessity, refraining from making pronouncements on the responsibility of the relevant international organization which is not before the court will inevitably produce a truncated narrative of blameworthiness. It is better to have issues of shared responsibility adjudicated by just one mechanism, located as closely as possible to the source of the violation but, nevertheless, independent of the tortfeasors.

In this respect, Blokker suggests to centralise dispute-resolution with regard to international organizations or international organization-connected action primarily within the international organizations themselves. International organization mechanisms, exclusively staffed with experts in international institutional law, may be more alive to the realities of joint international organization-member State action, as a result of which their decisions may be easier to implement than decisions of outside courts, in particular member State courts. A general arbitration mechanism with appeals competences may supervise these mechanisms and ensure consistency of application of the law, in ways that dispersed member State or regional courts cannot. Whether such internal mechanisms will actually be established, however, is uncertain. Blokker may well argue that these will increase the international organization's legitimacy - which in the current accountability era suffers owing to the absence of meaningful remedies available to aggrieved parties — but it remains to be seen whether international organizations will overcome their historical aversion to legal claims. The non-implementation, after almost 70 years, of Section 29 of the 1946 General Convention on Privileges and Immunities, providing that the UN shall make provisions for appropriate modes of settlement of disputes arising out of contracts or other disputes of a private law character to which the United Nations is a party, does not bode well in this regard. Interest groups and member States should not let up in their efforts to have such modes established. The big stick of member State responsibility carried by courts, in particular domestic courts, may naturally ensure that reformist efforts steered by member States do not slacken. In this respect, the mechanism of member State responsibility, as applied in litigation, may be characterized as a means to assign blame to member States not just for not doing enough to prevent its own violations, but also for not doing enough to prevent and redress international organization failures without which its own violations would not have occurred. 
Since the ECtHR's Bosphorus judgment, it is common to posit that when member States accede to international organizations, they do not leave their international law obligations at home. ${ }^{28}$ International organizations may draw an institutional veil, but this veil could, under certain circumstances, be pierced or lifted. Where the member States are clearly visible behind the veil, their responsibility for wrongful acts within an institutional context could be engaged, whether or not alongside the responsibility of the international organization. This visibility becomes even stronger where member States use their discretion within an institutional context and act in a fully autonomous fashion: in this scenario, the institutional veil metaphor does not even seem apt.

The potential for member State responsibility is an almost inevitable consequence of the complex interplay between international organizations and member States in decision-making and implementation. Member States integrate international organization decision-making organs and, in furthering their own national interests, may thus influence eventual decisions. Member States also play a key role in the implementation of international organization decisions, as international organizations do not always possess their own lawenforcement agencies. When wrongful acts occur in the context of such institutional decision-making and implementation, member States may well be held responsible given their proximity to the act.

Irrespective of any contemporary international organization-member State interaction in decision-making or implementation, it may even be argued that member States have a continuous obligation - possibly under primary norms of international law - to monitor and check the exercise of competences by international organizations, even if they were not involved in the actual exercise. It is then the very failure to properly 'manage the authority' of an international organization causing injury to third parties that engages the responsibility of the member State. This power and influence which member States exercise over international organizations, regardless of the latter's

28 Bosphorus, supra note 18, para. 154:

In... establishing the extent to which a State's action can be justified by its compliance with obligations flowing from its membership of an international organization to which it has transferred part of its sovereignty, the Court has recognised that absolving Contracting States completely from their Convention responsibility in the areas covered by such a transfer would be incompatible with the purpose and object of the Convention. 
separate legal personality and functional autonomy, ultimately constitutes the basis for a member-State responsibility paradigm. In given cases, the establishment of such responsibility by courts and tribunals may leave a lot to be desired, for practical, procedural, and political reasons. Regardless of the limitations of dispute-settlement, however, the development of a more mature, theoretically grounded doctrine of member State responsibility has the potential to change member States' calculations when acting within institutional settings, through mechanisms of value-internalization, or political (including civil society) pressure. 